\title{
Correction to: Pentachlorophenol Biodegradation by Citrobacter freundii Isolated from Forest Contaminated Soil
}

\author{
Rim WerheniAmmeri • Sonia MokniTlili • \\ Ines Mehri • Souhir Badi • Abdennaceur Hassen
}

Published online: 20 November 2017

(C) Springer International Publishing AG 2017

\section{Correction to: Water Air Soil Pollut \\ https://doi.org/10.1007/s11270-016-2959-Z}

One of the bibliographic reference entry of this article had the author name and family name switched by mistake.

Melina, N., Gonzalo, H. S., Gaston, A. C., Marcelo, S., Jorge, F.G., \& Silvia, E. M. (2013). Hydrocarbon biodegradation and dynamic laser speckle for detecting chemotactic responses at low bacterial concentration. Journal of Environmental Sciences, 25(3), 613-625.

Should be:

Nisenbaum, M., Sendra, G. H., Cerdá Gilbert, G.A., Scagliola, M., González, J.F. \& Murialdo, S.E. (2013). Hydrocarbon biodegradation and dynamic laser speckle for detecting chemotactic responses at low bacterial concentration. Journal of Environmental Sciences, 25(3), 613-625.

The online version of the original article can be found at https://doi.org/10.1007/s11270-016-2959-Z

R. WerheniAmmeri $(\bowtie) \cdot$ S. Badi

Centre of Research and Technologies of Water (CERTE),

Laboratory of Treatment and Recycle of wastewater, BP 273,

Soliman, 8020 Tunis, Tunisia

e-mail: rimwerheni@gmail.com

S. Badi

e-mail: taher.Souhir@yahoo.fr

R. WerheniAmmeri · S. MokniTlili · I. Mehri · S. Badi •

A. Hassen

Faculty of Mathematical, Physical and Natural Science of Tunis, (FST) El Manar University, University El Manar, 2092 Tunis,

Tunisia

S. MokniTlili

e-mail: mt_sonia@yahoo.fr

I. Mehri

e-mail: ines_mehri@yahoo.fr

A. Hassen

e-mail: abdohas@gmail.com 